\title{
URGENCY ANALYSIS AND IDENTIFICATION OF WEAKNESSES IN IMPLEMENTATION OF ACCOUNTABILITY SYSTEM PERFORMANCE OF GOVERNMENT INSTITUTIONS (SAKIP) TANAH BUMBU REGENCY 2015-2021
}

\author{
Rooswandi Salem ${ }^{1}$, Andi Tenri Sompa ${ }^{2}$, Samahuddin Muharram ${ }^{3}$ \\ ${ }^{1,2,3}$ Universitas Lambung Mangkurat, Indonesia
}

Received: 2 March 2021

Article Info

Accepted: 31 March 2021

Published: 9 April 2021

\section{Keywords:}

Identification of Weaknesses Urgency Analysis

Accountability System

SAKIP

Tanah Bumbu Regency

\begin{abstract}
Over time, performance measurement in government agencies has changed orientation, namely performance measurement, which is input-oriented (more specifically budget), shifting to performance measurement result-oriented. This study aims to evaluate the problems and factors that are involved. Affect the effectiveness of the implementation of the Accountability System Performance of Government Institutions (SAKIP) in the Tanah Bumbu Regency government. This study also explores the classification level of implementation and the leading performance indicators in SAKIP in the SKPD Tanah Bumbu Regency to determine the obstacles in implementing SAKIP. This research is a qualitative-quantitative study (mix method) using a case study approach. The approach used is a case study approach that focuses intensively on a particular object that studies it as a case. Meanwhile, the Likert scale's quantitative approach describes the urgency in the form of tables and percentages. The data strengthened by a qualitative narrative that adapts to identifying weaknesses based on quantitative analysis. The weaknesses found in this study cover all aspects, starting from understanding and elaborating the vision and mission and strategic plans of Tanah Bumbu Regency. Mapping of performance targets, a stipulation of performance planning documents, implementation of policies, programs and activities; performance evaluation, performance control, and improved performance.
\end{abstract}

\section{Copyright and License:}

Authors retain copyright and grant the journal right of first publication with the work simultaneously licensed under a Creative Commons Attribution 4.0 International License that allows others to share the work with an acknowledgement of the work's authorship and initial publication in this journal.

\section{INTRODUCTION}

Bureaucratic reform carried out by the Republic of Indonesia's government is currently a critical agenda to support all parties, both from the state apparatus and citizens' elements. Because the success in bureaucratic reform will be able to form good governance. The public's trust in the 
government will be even higher to carry out its duties and functions correctly and ultimately create a just and prosperous society under the Indonesian state's objectives as stated in the Preamble to the 1945 Constitution (Ratna \& Nasrah, 2016). The existence of reform euphoria and the open flow of information about government programs in the reform era created many opportunities for the public to know, follow, assess, and criticise government programs. The government is required to improve its governance, to implement the concept of good governance (Murdi \& Putri, 2020).

Therefore, Government Regulation Number 8 of 2006 concerning Financial Reporting and Performance of Government Agencies mandates that every government agency is also required to prepare a performance report in addition to financial reports. Performance is the output/result of activities/programs to be or achieve in connection with the budget with measurable quantity and quality. Local government agencies must be responsible for carrying out their primary duties and functions to the public and responsibility for fulfilling public demands for local government performance. Over time, the measurement of performance in local government agencies has changed orientation, namely performance measurement, which is input-oriented (more specifically budget), shifting to performance measurement result-oriented (Asmoko, 2014; Murdi \& Putri, 2020). But in fact, the concept of Accountability is still not in line with the work culture in Indonesia. Many parties interpret Accountability as limited to financial / budget accountability reporting. This situation results in a government agency that has reported the allocation of funds used to be deemed responsible for its activities regardless of whether the activities carried out to provide benefits for improving the welfare of the community or improving the performance of the agency (Rangkuti, 2018; Purnomo \& Hafidz \& Djauhari, 2018).

Over time, performance measurement in government agencies has changed orientation, namely performance measurement, which is input-oriented (more specifically budget), shifting to performance measurement result-oriented (Asmoko, 2014). This measurement was clarified in writing by the issuance of a package of laws in the field of State finance (Law Number 17 of 2003 concerning State finances, Law Number 1 of 2004 concerning State Treasury and Law Number 15 of 2004 concerning Audit of the Management and Accountability of State Finances).

The government performance measurement system's implementation has been regulated in Presidential Instruction No. 7 of 1999 concerning Accountability for Government Agencies' Performance (AKIP). The PANRB Ministry has provided SAKIP technical guidance and assistance to 84 ministries/institutions with 418 work units, 34 provincial governments with 1,027 Regional Apparatus Organizations (OPD) and 514 districts/cities with 20,756 OPDs in 2019. Implementing SAKIP in district/city governments is one of the government's concrete steps to realise bureaucratic reform through effective and efficient budget management. As a realisation, every year, the PANRB Ministry carries out an evaluation of the implementation of SAKIP in all ministries, institutions and local governments to measure the development of SAKIP implementation and provide guidance sustainable throughout all government agencies. The evaluation carried out to map government agencies into several categories. There are as many as 161 Regency or city and Provincial Governments in Region II who are given their evaluation results and recommended to make improvements in the following year, one of which is the Tanah Bumbu Regency Government (Tanbu) (Mata Banua, 2020).

Based on the evaluation submitted by the PANRB Ministry, Tanah Bumbu Regency won the predicate B. The results of the SAKIP assessment received by the Tanbu Regency Government were very encouraging and encouraged to continue to work diligently in government administration (Mata Banua, 2020). Government Regulation's mandate evaluates SAKIP itself No. 8/2006 on Financial Reporting and Performance of Government Agencies and Presidential Regulation No. 29/2014 on SAKIP. 
The increase in the title obtained by the Tanah Bumbu Regency Government is significant in the last few years. Previously, Tanah Bumbu District at the end of 2018 related to SAKIP's status had upgraded from CC to B status. SAKIP Tanah Bumbu Regency in the previous years had the CC predicate until 2017.

Specifically, this study aims to evaluate the problems and factors that are involved. Affect the effectiveness of the implementation of the Accountability System Performance Of Government Institutions (SAKIP) in the Tanah Bumbu Regency government. This research focuses on the factors of SAKIP Guidelines, Local Government Commitment, Work Culture and the role Apparatus of the Government Internal Supervisory(APIP). This study also explores the classification level of implementation and the leading performance indicators in SAKIP in the SKPD Tanah Bumbu Regency to determine the obstacles in implementing SAKIP in the Tanah Bumbu Regency government environment. The difference is this study evaluates or assesses the level of implementation and leading performance indicators in Tanah Bumbu Regency based on the Regulation of the Minister of State Apparatus Empowerment and Bureaucratic Reform No. 13/2010 concerning Implementation Guidelines for Performance Accountability Evaluation of Government Agencies in 2010.

\section{METHODOLOGY}

This research is a qualitative-quantitative study (mix method) using a case study approach. The approach used is a case study approach that focuses intensively on a particular object that studies it as a case. Case study research intended to study intensively the background of the problem, the circumstances, the position of an ongoing event, and the environmental interactions of specific social units that are what they are (Gunawan, 2016). Furthermore, Danim (Gunawan, 2016) argues that the subject under study is relatively limited in case study research, but the variables and focus studied are extensive in dimensions. The definition of a case study developed by Creswell (2009) states that case study research is research carried out on an object, which is referred to as a case that is carried out completely, thoroughly, and using various kinds of data sources. Case study research is an in-depth study of a particular social unit, and the results of the research will provide a broad and in-depth picture of that social unit.

Meanwhile, the Likert scale's quantitative approach describes the urgency in the form of tables and percentages. The data strengthened by a qualitative narrative that adapts to identifying weaknesses based on quantitative analysis. The Likert scale describes perceptions of stakeholder regarding SAKIP problems in their work environment. The perception is then given a descriptive explanation with written answers in the questionnaire to deepen the problem. At the end of the discussion, it equipped to explain the problems, priority resolution and policy recommendations.

Secondary data obtained from central and regional regulations related to SAKIP, the 20162021 Tanah Bumbu District Medium Term Development Plan (RPJMD), Tanah Bumbu Regency IKU (2017, 2018 and 2019), Regional Government Work Plans (RKPD) Tanah Bumbu Regency (2017, 2018 and 2019), SAKIP Evaluation Result Report (LHE), SAKIP OPD evaluation results, Government Agency Performance Accountability Report (LAKIP), as well as the Inspectorate's Annual Performance Report (LKJ), and Tanah Bumbu Regency Government. Researchers also use various documents relevant to the research focus, such as books, journal articles, other government documents, archives, and other supporting documents. Meanwhile, data collection techniques and instruments are documentation by collecting data in documents regarding the Government Agency Performance Accountability System (SAKIP). Data processing and analysis techniques carried out by collecting data/facts accompanied by interpretation of the data obtained and analysed qualitatively-quantitatively using a case study approach. 


\section{FINDINGS AND DISCUSSION}

Policy evaluation is an activity that involves estimating or assessing policies that include substance, implementation and impact (Anderson: 1975 in Budi Winarno). Policy evaluation is seen as functional activity. This activity means that policy evaluation is not only carried out at the final stage but for the entire policy process. According to W. Dunn, the term evaluation has a related meaning, each of which refers to applying several value scales to the results of policies and programs. The evaluation includes conclusions, clarifications, criticisms, adjustments and reformulation of the problem.

Policy evaluation is a process to assess how far a policy produces results, namely by comparing the results obtained with the stated policy goals or targets (Nurharjadmo, 2008). Evaluation is an assessment of an issue that generally points to the merits of the problem. A program evaluation is usually carried out to measure a program's effectiveness in achieving the stated goals (Hanafi \& Guntur, 1984: 16). Policy evaluation carried out to determine four aspects, namely:

1) the policymaking process

2) the policy implementation process the policy

3) consequences,

4) the policy impact effectiveness (Wibowo, 1994: 9).

In the public policy process, policy implementation is essential, even more critical than Udoji's policymaking (Nurhajatmo, 2008). Policy implementation is a bridge that connects policy formulation with expected policy outcomes.

Every year the PANRB Ministry carries out an evaluation of the implementation of SAKIP in all agencies, both Ministries, Institutions, and Provincial / Regency / City Government. Also, through the internal supervisory apparatus, each government agency must evaluate the implementation of SAKIP in their respective environment. The evaluation was carried out by referring to the PANRB Ministerial Regulation Number 12 of 2015 concerning Guidelines for the Evaluation of the Implementation of the Performance Accountability System for Government Agencies. The regulation explains that the evaluation of the implementation of SAKIP is a systematic analysis activity, assigning values, attributes, appreciation, and recognition of problems and providing solutions to problems found to increase the performance accountability of government agencies/work units. The evaluation carried out is more focused on data collection and analysis to build arguments for the formulation of suggestions/recommendations for improvements to be persuasive, analytical and pay attention to the possibility of their application (Raharja, 2018).

Based on the PANRB Ministerial Regulation Number 12 of 2015 concerning Guidelines for evaluating the Performance Accountability System for Government Agencies. It stated that the evaluation carried out on the components of performance planning (30\%), performance measurement $(25 \%)$, performance reporting $(15 \%)$, evaluation internal $(10 \%)$, and performance achievements (weight 20\%). From this explanation, it can conclude that the evaluation is more focused on the implementation of the SAKIP cycle, from planning to internal evaluation with a total weight of $80 \%$.

Table 1 Components, sub-components, and evaluation weights of SAKIP

\begin{tabular}{|l|l|l|l|l|}
\hline Components & Weights of & & Sub-components & \\
\hline 1. Planning & $30 \%$ & a. & Plans Strategic (10\%), including: & \\
\hline performance & & & Renstra fulfillment(2\%), Renstra quality \\
\hline & & & $(5 \%)$, and Strategic Plan implementation (3\%). & \\
\hline & & b. & Planning Performance Pual $\quad$ Annual \\
\hline & & covering fulfillment of RKT (4\%), quality of & \\
\hline
\end{tabular}

International Journal of Politic, Public Policy and Environment Issues, Vol.1, No.1, April 2021 


\begin{tabular}{|c|l|l|l|}
\hline & & & RKT (10\%), and implementation of RKT (6\%). \\
\hline 2. Measurement $25 \%$ & a. & Fulfilment measurement (5\%) \\
\hline Performance & & b. & Measurement quality (12.5\%) \\
\hline & & c. & Implementation of measurement (7.5\%) \\
\hline 3. Reporting & $15 \%$ & a. & Fulfilment of reporting (3\%) \\
\hline Performance & & b. & Reporting quality (7.5\%) \\
\hline & & c. & Utilisation of reporting (4.5\%) \\
\hline 4. Evaluation & $10 \%$ & a. & Fulfilment of evaluation (2\%) \\
\hline Internal & & b. & Quality of evaluation (5\%) \\
\hline & & c. & Utilisation of evaluation results (3\%) \\
\hline 5. Outcomes of $20 \%$ & a. & Performance reported (output) (5\%) \\
\hline Performance & & b. & Reported performance (outcome) (10\%) \\
\hline & c. & year performance (benchmark) (5\%) \\
\hline
\end{tabular}

Source: Regulation of the Minister of PANRB Number 12 of 2015

The scope of evaluation on the implementation of SAKIP includes evaluation activities on performance planning and performance agreements, including implementing performance-based budgets, implementing programs and activities, performance measurement, performance reporting, internal evaluation, and performance achievement by taking into account the results of the previous year's evaluation. Important issues to be addressed through an evaluation of the implementation of SAKIP are as follows:

1) Government agencies/work units / SKPD in preparing, reviewing and refining performance planning focuses on results;

2) Development of performance measurement and data collection system;

3) Disclosure of information on performance achievements;

4) Monitoring and evaluation of the achievement of program implementation performance, especially strategic programs;

5) The linkage among all components of performance planning with budgeting, implementation and control policies as well as reporting;

6) Main performance achievements of each government agency/work unit / SKPD;

7) Level of implementation of SAKIP;

8) Ensure that an action plan is drawn up on the evaluation results recommendations that have not been followed up.

Evaluation of the implementation of SAKIP consists of evaluating the implementation of performance management components, including performance planning, performance measurement, performance reporting, internal evaluation, and performance achievements. Assessment of performance planning components, performance measurement, performance reporting, and internal evaluation is an assessment of SAKIP. Simultaneously, the performance achievement component is an assessment of the performance of the implementation of SAKIP (Raharja, 2018).

In connection with the problem, this research will evaluate the effectiveness of implementing the Performance Accountability System of Tanah Bumbu Regency Government Agencies. Evaluation studies are activities to assess or see the success and failure of an organisation or work unit in carrying out the tasks and functions assigned to it. The Government Agency Performance Accountability System (SAKIP) was first implemented in Indonesia through Presidential Instruction No. 7 of 1999. This Presidential Instruction requires all government agencies to prepare a Government Agency Performance Accountability Report (LAKIP) as a form of performance accountability. It expected to improve its performance, however, until 2013, the success of implementing this Inpres has yet to be proven (Jurnali \& Nabiha, 2015) (Jurnali \& Siti- 
Nabiha, 2015). Government agencies implement SAKIP only ceremonially to comply with central government regulations and ignore the efficiency and effectiveness of funds (Sihaloho \& Halim, 2005).

The Government Performance Accountability System is an integrated system to fulfil governmental obligations to account for the success or failure of implementing government organisations' vision and mission (Mariandini \& Irianto \& Nurkholis, 2018). The Government Agency Performance Accountability System is an instrument used by government agencies in fulfilling their obligations to account for the success and failure of the implementation of the organisation's mission (LAN \& BPKP, 2000). In another sense, the Government Agency Performance Accountability System (SAKIP), according to Asmoko (2014) is an integration of the planning system, budgeting system and performance reporting system, which is in line with the implementation of the financial accountability system.

This ultimately mandates that every government agency is also required to prepare performance reports in addition to financial reports. Performance is the output/result of activities/programs that are to be achieved in connection with the use of the budget with measurable quantity and quality. All Government Agencies are required to prepare a Performance Report every year. This is a form of strengthening Performance Accountability by implementing the Government Agency Performance Accountability System (SAKIP). Performance reporting is known as the Government Agency Performance Accountability Report (LAKIP). The Government Agency Performance Accountability Report (LAKIP), according to Asmoko (2014) is a Government Agency Performance Accountability Report. LAKIP is the final product of SAKIP, which describes the performance achieved by a government agency on the implementation of programs and activities funded by the APBN / APBD. The preparation of LAKIP based on a budget cycle that runs for 1 year (Asmoko, 2014).

Based on Government Regulation Number 8 of 2006 concerning Financial Reporting and Performance of Government Agencies and Presidential Regulation Number 29 of 2014 concerning the Government Agency Performance Accountability System (SAKIP), the Inspectorate Team of South Kalimantan Province coordinated by the Ministry of State Apparatus Empowerment and Bureaucratic Reform has carried out an evaluation of the implementation Government Agency Performance Accountability System for reporting the performance of Tanah Bumbu Regency in 2017, 2018 and 2019. Evaluation is carried out based on the Regulation of the Minister of State Apparatus Empowerment and Bureaucratic Reform Number 12 of 2015 concerning Guidelines for Evaluating the Implementation of the Performance Accountability System of Government Agencies. The evaluation aims to assess the level of performance accountability or Accountability for the results (outcomes) to use the budget to create result-oriented government and provide recommendations for the necessary improvements.

The evaluation results show that the Tanah Bumbu Regency Government received a score of 65.97 or the predicate "B". This evaluation shows the effectiveness and efficiency of budget use compared to its performance achievements and the quality of cultural development of bureaucratic performance and outcome-oriented government administration in the district government. Tanah Bumbu is already showing promising results but still needs improvement.

A brief description of the evaluation results referred to is summarised as follows:

1) Regional leaders, together with the heads of Regional Government Work Units (SKPD) have made efforts to improve the performance management system, which is shown by a commitment to perfecting the formulation of results-oriented goals and objectives and their indicators in planning documents in the sample SKPD-SKPD; 
2) Preparation of the SKPD Performance Agreement that has been stipulated includes a cascade down to echelon IV level;

3) SKPD performance targets have not been fully used as the basis for selecting programs and activities so that there are still programs and activities that are less efficient and effective in achieving the goals and objectives;

4) The strategic target performance indicators in SKPD are not fully resulted oriented and relevant to the targets achieved;

5) The quality of SKPD performance measurement is not fully oriented towards program performance achievement, still on the implementation of activities and budget implementation;

6) Performance reports have been prepared down to the SKPD level, but the contents of the report still reveal a lot of activity implementation and budget absorption, have not fully presented an analysis of program performance achievement and have not been able to present an analysis of the efficiency and effectiveness of budget use towards performance achievement; and

7) The program's evaluation has not been fully able to show the effectiveness of the program carried out by each SKPD because it is not oriented towards program performance and only program/activity implementation and budget absorption.

Tanah Bumbu Regency is a young district in South Kalimantan, geographically located in the southeastern region of Kalimantan Island, with a diversity of natural resources. Tanah Bumbu Regency also has a thick regional culture so that people's life has a strong character in filtering western culture. In this regard, Tanah Bumbu Regency's development has a strong cultural foundation, especially in building the community's socio-economy. Tanah Bumbu Regency has passed 14 (fourteen) years of development since it was split from the main district in 2003. Tanah Bumbu Regency continues to improve and build to align its position with other districts/cities in South Kalimantan Province.

In the research that has been done, there are several essential aspects. The results show that there are still weaknesses in the implementation of SAKIP in Kab. Tanah Bumbu in all aspects of SAKIP, namely works planning, performance measurement, performance reporting and performance evaluation. In understanding the urgency of SAKIP, the resulting score is relatively high, namely 210 for work planning, 210 for performance measurement, 208 for performance reporting, and 208 for performance evaluation, from the maximum score of 225 determined in this study. As for the implementation aspect, the resulting scores are lower than these scores, namely 187 for work planning, 188 for performance measurement, 187 for performance reporting, and 186 for performance evaluation, out of a maximum score of 225 . The score is quite close to the minimum value for a good score, namely 180 .

The weaknesses found are as follows: in the determination/planning stage, namely joint commitment to achieving the vision and mission of Tanah Bumbu regency, the ability to describe strategic plans, limited competent human resources in operating information technology-based databases, planning capacity, optimisation of annual performance planning, guidelines for the preparation of performance indicators, resource management, and assistance from the central and provincial governments; the implementation stage, namely the understanding of the implementation of SAKIP, the competence of human resources in the implementation of performance management, the dominant database using manual systems, and coordination between organisations and between internal organisational units; the evaluation stage, namely the capacity of employees / apparatus in the preparation of performance reports, consistency and continuity of the implementation of performance evaluation, the validity of the database in the assessment of performance indicators, and the availability of human resources and budget for the implementation of information technology-based performance measurement; the control stage, namely cooperation between all elements in preparing valid data related to performance achievements, and the absence of tools that regulate rewards and punishments for performance and discipline achievements; the 
continuous improvement stage, namely the use of evaluation results for continuous improvement / performance enhancement.

District Government Apparatus. Tanah Bumbu has an awareness/understanding of the Government Agency Performance Accountability System (SAKIP). As for the implementation, it is still in assessment excellent. As shown in the graph of the average Likert scale score for each SAKIP variable, as follows:

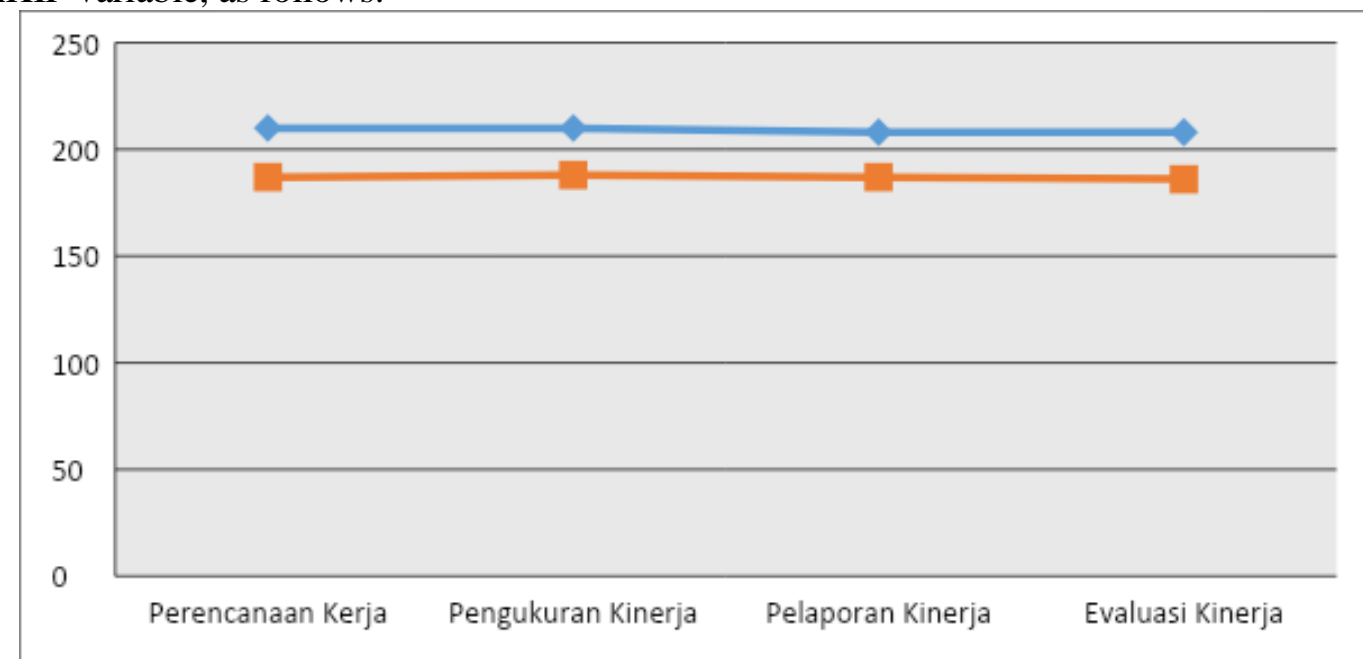

Figure 1. An average score of awareness and implementation of SAKIP in Tanah Bumbu Regency

The graph above shows that at the level of awareness/understanding of the urgency, the Likert score is quite far above the minimum threshold for excellent value (180). While the implementation performance score is very close to the minimum score threshold is very good. In this case, it concluded that the awareness/understanding and implementation performance are not yet symmetrical. There are still weaknesses in the implementation of the Government Agency Performance Accountability System (SAKIP). The important note is that the score based on assessing the Tanah Bumbu Regency government apparatus itself. In this case, it concluded that the Tanah Bumbu Regency government apparatus was aware of these weaknesses.

The weakness of implementing the Government Agency Accountability System (SAKIP) in Tanah Bumbu Regency based on the previous discussion was then studied in depth using the USG model, namely urgency, seriousness, and growth. Urgency, namely how urgent an issue must resolve; Seriousness, namely how earnest the consequences must resolve an issue it will cause; Growth, namely how likely it is that the issue will worsen if it is not addressed immediately.

Table 2. Matrix Analysis Weakness

\begin{tabular}{|l|l|l|l|l|l|l|}
\hline No. & Weaknesses & \multicolumn{2}{l|}{ Total } & Priority \\
\cline { 3 - 5 } & & Score & S & G & Score & \\
\hline 1 & Determination of & $\begin{array}{l}\text { Planning documents yet synergistic, both cascade down or } \\
\text { cascade up. This, of course, dramatically affects the } \\
\text { determination of the performance plan. In this case, the set's } \\
\text { performance plans are often not following the Strategic } \\
\text { Plan. }\end{array}$ & 5 & 5 & 15 & I \\
\hline 2 & $\begin{array}{l}\text { The lack of commitment from the top leaders to achieve a } \\
\text { shared vision and mission, so that performance management }\end{array}$ & 5 & 5 & 15 & I \\
\hline
\end{tabular}




\begin{tabular}{|l|l|l|l|l|l|l|}
\hline & $\begin{array}{l}\text { has not focused on the same goals to achieve, or there are } \\
\text { too many goals to be achieved so that is not focused and } \\
\text { not focused }\end{array}$ & $\begin{array}{l}\text { It has limited human resources that are reliable in the } \\
\text { database, especially those capable of operating system } \\
\text { databases based on information and communication } \\
\text { technology. This system affects the accuracy of mapping } \\
\text { targets and performance targets. }\end{array}$ & 4 & 3 & 12 & I \\
\hline 4 & $\begin{array}{l}\text { Performance planning is not optimal, which includes } \\
\text { synergy or a logical relationship between the formulation of } \\
\text { goals, objectives and strategic programs,and the setting of } \\
\text { targets and indicators. }\end{array}$ & 5 & 5 & 15 & I \\
\hline
\end{tabular}

In principle, all the weakness points contained in the matrix above are in an urgent position to be resolved. This weakness means, if not resolved, the Government Agency Performance Accountability System (SAKIP) in Kab. Tanah Bumbu will not improve / increase / maximum achievement. Some weaknesses become priorities II and III to be resolved based on an analysis related to the level of seriousness and growth. In this case, the impact of the problem could be caused and worsening the situation/performance.

\section{CONCLUSION}

The weaknesses found in this study cover all aspects, starting from understanding and elaborating the vision and mission and strategic plans of Tanah Bumbu Regency; mapping of performance targets and targets; stipulation of performance planning documents; implementation of policies, programs and activities; performance evaluation; performance control; and, improved performance. The important note is that the score based on assessing the Tanah Bumbu Regency government apparatus itself. In this case, it concluded that the Tanah Bumbu Regency government apparatus was aware of these weaknesses.

The priority classification above becomes a consideration for determining policies, programs and activities that must be prioritised to improve the Government Agencies Performance Accountability System (SAKIP) in Kab. Tanah Bumbu will not improve / increase / maximum achievement. However, all of these weaknesses need to resolve to reach a maximum level of implementation. Several policy recommendations that need to be further developed are establishing policies requiring all SKPDs, District Governments, and Village Governments in Kab. Tanah Bumbu to carry out the vision and mission, and strategic plans of the District Government. Tanah Bumbu and made a database system development program based on information technology, either independently or in collaboration with information technology-based database system service providers, for all district government levels.

\section{REFERENCES}

Asmoko, H. (2014). Evaluasi Sistem Pengukuran Kinerja Pemerintah Pusat Di Indonesia. Jakarta Creswell, John W., (2013). Qualitative Inquiry and Research Design Choosing among Five. Approaches. Third Edition.

Gunawan, I. (2016). Metode Penelitian Kualitatif Teori \& Praktik. Jakarta: Penerbit Bumi Aksara.

Jurnali, T., \& Nabiha, A.K., (2015). Performance Management System For Local Government: The Indonesian Experience. Global Business Review. Vol. 16 No, pp. 351-63.

LAN dan BPKP. (2000). Akuntabilitas Dan Good Governance (Modul Sosialisasi Sistem AKIP). Modul 1 Dari 5. Jakarta: LAN.

LAN dan BPKP. (2000).. Evaluasi Kinerja Instansi Pemerintah (Modul Sosialisasi Sistem AKIP), Modul 4 Dari 5. Jakarta: LAN.

LAN dan BPKP. (2000).. Pengukuran Kinerja Instansi Pemerintah (Modul Sosialisasi Sistem 
AKIP). Modul 3 Dari 5. Jakarta: LAN.

LAN dan BPKP. (2000).. Penyusunan Laporan Akuntabilitas Kinerja Instansi Pemerintah (Modul Sosialisasi Sistem AKIP). Modul 5 Dari 5. Jakarta: LAN.

LAN dan BPKP. (2000).. Perencanaan Strategik Instansi Pemerintah (Modul Sosialisasi Sistem AKIP). Modul 2 Dari 5. Jakarta: LAN.

Mariandini, F. I \& Irianto, G \& Nurkholis. (2016), Institusionalisasi Sistem Akuntabilitas Kinerja Instansi Pemerintah di Pemerintah Kota Malang.

Mata Banua. 2020. Kabupaten Tanah Bumbu Raih Predikat SAKIP B+ 2019. 29 Januari (2020). Selengkapnya di matabanua.co.id/2020/01/29/kabupaten-tanah-bumbu-raih-predikat-sakip-b2019/. Diakses pada 30 Agustus 2020.

Ministry of Kemenpan RB. (2015-2019). Assessment Documents Of Sakip Assessment Of Bumbu District From The Ministry Of Kemenpan Rb 2015-2019

Nurharjadmo, W.. (2008). Evaluasi Implementasi Kebijakan Pendidikan Sistem Ganda di Sekolah Kejuruan. Spirit Publik. Vol. 4. No. 2. pp. 215-228.

Purnomo, I.D. \& Djauhari, H. J. (2018). Implementasi Sistem Akuntabilitas Kinerja Instansi Pemerintah (Sakip) Dalam Pelaporan Akuntabilitas Kinerja Polri Berdasarkan Peraturan Presiden Ri Nomor 29 Tahun 2014 (Studi Kasus Di Polda Jateng). Jurnal Hukum Khaira Ummah. Vol. 13. No. 1.

Rangkuti, M H B. (2018). Akuntabilitas Kinerja di Instansi Pemerintah. Jurnal Akuntansi Bisnis \& Publik, Vol 8 No 2.

Ratna, I \& Nasrah, H. (2016). Pengaruh Pengelolaan Keuangan Daerah Terhadap Penerapan Sistem Akuntabilitas Kinerja Instansi Pemerintah Di Lingkungan Pemerintah Provinsi Riau. Kutubkhanah: Jurnal Penelitian Sosial Keagamaan. Vol.19, No.1. 